\title{
Development of an Advanced Approach for Next Generation, High Resolution, Integrated Reservoir Characterization
}

\author{
Quarterly Technical Progress Report \\ July 1 - September 30, 2003
}

Scott R. Reeves

Jack W. Steen

November, 2003

\section{DE-FC26-01BC15357}

Advanced Resources International

9801 Westheimer, Suite 805

Houston, TX 77042 


\section{$\underline{\text { U.S. Department of Energy Disclaimer }}$}

This report was prepared as an account of work sponsored by an agency of the United States Government. Neither the United Sates Government nor any agency thereof, nor any of their employees, makes any warranty, express or implied, or assumes any legal liability or responsibility for the accuracy, completeness, or usefulness of any information, apparatus, product, or process disclosed, or represents that its use would not infringe privately owned rights. Reference herein to any specific commercial product, process, or service by trade name, trademark, manufacturer, or otherwise does not necessarily constitute or imply its endorsement, recommendation, or favoring by the United States Government or any agency thereof. The views and opinions of authors expressed herein do not necessarily state or reflect those of the United Sates Government or any agency thereof.

\section{$\underline{\text { Advanced Resources International Disclaimer }}$}

The material in this Report is intended for general information only. Any use of this material in relation to any specific application should be based on independent examination and verification of its unrestricted applicability for such use and on a determination of suitability for the application by professionally qualified personnel. No license under any Advanced Resources International, Inc., patents or other proprietary interest is implied by the publication of this Report. Those making use of or relying upon the material assume all risks and liability arising from such use or reliance. 


\begin{abstract}
$\underline{\text { Abstract }}$
During this reporting period all preliminary tasks were completed (such as the creation of a flexible project database) and construction of the actual broadband transform function was begun. Analysis of intermediate results performed during the reporting period has proven that the neural networks being used can accurately predict data elements using surface seismic or crosswell seismic data and attributes as input.
\end{abstract}




\section{Table of Contents}

1.0 Executive Summary

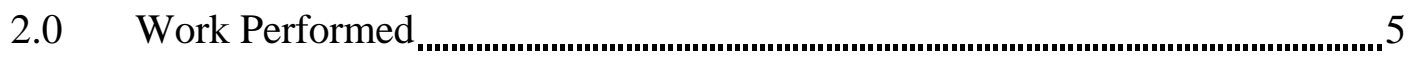

3.0 Results and Discussion

4.0 Conclusions

$5.0 \quad$ References 


\subsection{Executive Summary}

During this reporting period all preliminary tasks were completed (such as the creation of a flexible project database) and construction of the actual broadband transform function was begun. Analysis of intermediate results performed during the reporting period has proven that the neural networks being used can accurately predict data elements using surface seismic or crosswell seismic data and attributes as input. 


\subsection{Work Performed}

\section{Task 1: $\quad$ Select Test Site}

Task completed. No work was performed on this task during the reporting period.

Task 2: $\quad$ Collect and Process Data

Task completed. No work was performed on this task during the reporting period.

Task 3: $\quad$ Develop Broadband Seismic Transform Function

During this reporting period we were able to begin work on the broadband seismic transform function. Artificial Neural Networks (ANN) were constructed and training of the networks commenced. Quality of the output predictions was assessed periodically as network training progressed to confirm continued improvement in output correlation. Network training proved to take longer than initially anticipated because of the large data set size and computational capabilities of the computers being used. However, the network converged in a reasonable amount of time and continued to progress. A number of different network configurations (architectures) were computed simultaneously. Selection of the optimum network architecture is a somewhat trial-anderror process; running as many as six networks simultaneously avoided lost time due to serial architecture investigations.

Individual networks were formed to effect the prediction of crosswell seismic traces and attributes using surface seismic traces and attributes as input, as well as prediction of well log suites using crosswell seismic traces and attributes as input. When combined in series and supplemented by the Engineering Model network these comprise the essential elements of the Broadband Seismic Transform function.

Careful analysis of network predictions is necessary at each intermediate stage of the broadband transform process to insure that the network is making accurate predictions. At the conclusion of the network training process all of the seismic traces in the entire survey will be cycled through the trained network yielding continuous predictions of porosity and permeability at each seismic trace location. Due to the simplicity of actual network calculations it is anticipated that processing the entire seismic survey in this manner will require very little time, perhaps only a few days.

\section{Task 4: $\quad$ Develop Integrated Engineering Model}

Task completed. No work was performed in this task during the reporting period.

\section{Task 5: $\quad$ Reservoir Characterization and Modeling}

No work was performed on this task during the reporting period. 


\section{Task 6: $\quad$ Technology Transfer}

During this reporting period the field operator continued to review the Topical Reports prior to their submission to NETL in Tulsa.

\subsection{Results and Discussion}

At the conclusion of this reporting period the various components of the broadband seismic transform function are under construction. A series of Artificial Neural Networks are being trained to recognize patterns in surface seismic and crosswell seismic data and to predict crosswell seismic and well logs, respectively. These will be serially coupled with the Engineering Model neural network to affect the broadband transform function.

Analysis of intermediate results from the individual networks has shown that good correlations are being obtained between predicted and measured data.

\subsection{Conclusions}

Creation of the broadband transform function is in its final stages. Output obtained from the transform function must be validated, and methods devised to use the output for reservoir characterization. These more conventional tasks will be undertaken as soon as complete output from the neural network process is available.

\subsection{References}

None. 